\title{
Diseminasi Pola Pengelolaan Keuangan Rumah Tangga: Perencanaan Biaya Pendidikan
}

\author{
Farida Komalasari'1), Eko Ganiarto2) \\ 1)Prodi IImu Administrasi Bisnis, Universitas Presiden, farida_k@president.ac.id \\ 2)Prodi IImu Manajemen, Universitas Presiden, eganiarto@gmail.com
}

\begin{abstract}
ABSTRAK
Rendahnya literasi keuangan ibu rumah tangga selaku pengelola keuangan rumah tangga di Indonesia mengakibatkan banyaknya rumah tangga yang tidak memiliki perencanaan biaya pendidikan. Hal ini mengakibatkan tingginya kasus putus sekolah yang disebabkan kurangnya biaya pendidikan. Kegiatan ini bertujuan untuk menyebarluaskan cara melakukan pengecekan kesehatan keuangan rumah tangga, meningkatkan kesadaran pentingnya perencanaan biaya pendidikan, dan memberikan pemahaman tentang cara melakukan perencanaan biaya pendidikan anak. Kegiatan diseminasi dilaksanakan pada Minggu, 2 Desember 2018 jam 16.05-18.00 dengan kelompok sasaran Komunitas Ibu RT 09 RW 03 Kelurahan Dukuh Kecamatan Kramat Jati Jakarta Timur. Acara dihadiri oleh 24 anggota komunitas. Diseminasi dilaksanakan dengan metode ceramah, kuis, tanya jawab, dan diskusi. Peserta sangat antusias dan aktif mengikuti seluruh rangkaian acara dan menginginkan dilakukannya acara sejenis dengan topik yang berbeda. Kegiatan diseminasi dengan topik yang berbeda dapat dilakukan pada kelompok sasaran yang sama atau berbeda. Topik yang diusulkan diantaranya adalah kiat menabung, memilih lembaga asuransi, memilih instrumen investasi, dan mendidik anak pada era digital.
\end{abstract}

Kata-kata kunci: Literasi Keuangan, Pengelolaan Keuangan Rumah Tangga,

Perencanaan Biaya Pendidikan

\begin{abstract}
How low the financial literacy of many housewives as the ones who are in charge of the family's finance in Indonesia causes many families who do not have an educational financial planning. This causes how common it is for some people who could not go to school because of their family's financial problem. The purpose of this program is to show how it is to maintain the family's financial status, to increase the awareness of how important educational financial planning is and to show how to plan their children educational finance. This program was held on Sunday, Dec $2^{\text {nd }}$ at $4.05-6.00 \mathrm{pm}$ and was participated by 24 community members. The visit was done by giving lecture, quiz, question \& answer, and discussion. The participants were really enthusiastic and active through the whole activity and wanting to attend the same activity with a different topic. An activity with different topic can be held with either the same or different community. The topics they suggested were how to save money, how to choose an insurance company, how to choose something to invest and how to raise children in a digital era.
\end{abstract}

Keywords: Financial Literacy, Household Financial Management, Educational

Financial Planning

\section{PENDAHULUAN}

Otoritas Jasa Keuangan (OJK) menyatakan bahwa literasi keuangan di Indoneisa adalah 67,8\% (OJK, 2017a). Angka ini tergolong rendah dibandingkan dengan negara berkembang lainnya, seperti Malaysia (81\%), Thailand (78\%), dan Singapura (96\%) (OJK, 2016a). Pada tahun 2019, angka literasi keuangan ini ditargetkan naik menjadi 75\% (OJK, 2017b).

Peningkatan angka literasi keuangan diperlukan untuk mewujudkan ketangguhan rumah tangga dalam pengelolaan keuangan keluarga. Keberhasilan rumah tangga dalam mendanai kegiatan rumah tangganya ditentukan oleh literasi keuangan pengelola rumah 
tangga. Salah satu kegiatan yang memerlukan pendanaan adalah pendidikan anak. Penelitian yang dilakukan oleh Pulungan (2016) menunjukkan bahwa literasi keuangan yang baik akan berdampak baik pada perilaku keuangan masyarakat; demikian juga sebaliknya. Oleh karenanya diperlukan upaya nyata untuk meningkatkan literasi keuangan masyarakat.

Di Indonesia, pengelola keuangan rumah tangga pada umumnya adalah perempuan. Berdasarkan kompas.com (2018), literasi keuangan perempuan Indonesia justru lebih rendah dibandingkan laki-laki. Penelitian yang dilakukannya menunjukkan bahwa $18,84 \%$ perempuan memiliki pemahaman keuangan yang cukup, sedangkan laki-laki sebesar 24,87\%. Sedangkan menurut OJK (2013) yang dikutip oleh thenewsavvy.com dalam kompas.com (2018) menunjukkan bahwa 56,65\% perempuan di Indonesia sudah mengetahui cara penggunaan uang yang tepat, sementara pada laki-laki mencapai $62,87 \%$. Oleh karenanya, sangat diperlukan upaya untuk meningkatkan literasi keuangan perempuan agar dapat melakukan pengelolaan keuangan rumah tangga dengan lebih baik.

Salah satu indikasi belum baiknya pengelolaan keuangan rumah tangga adalah tingginya non-performing loan (NPL) dari kartu kredit di Indonesia, yang telah terjadi sejak tahun 2009, yakni mencapai angka 8,7\% (Franedya \& Indradie, 2009). Bahkan pada tahun 2017, NPL terbesar BRI bersumber dari kartu kredit (Sembiring, 2018); yang sebagian besar pemakainya adalah rumah tangga.

Indikator lainnya adalah banyaknya siswa yang putus sekolah karena masalah biaya. Studi yang dilakukan oleh Pusat Studi Kependudukan dan Kebijakan Universitas Gajah Mada (PSKK-UGM, 2016) menunjukkan bahwa 47,3\% penyebab putus sekolah adalah masalah biaya, 31\% karena ingin membantu orang tua dengan bekerja, dan 9,4\% karena ingin melanjutkan ke pendidikan nonformal (kursus, masuk pesantren, dll.). Hal ini merupakan akibat tidak adanya perencanaan biaya pendidikan.

Biaya pendidikan adalah bentuk pengeluaran yang semestinya mudah direncanakan, karena jumlahnya dapat diprediksi dan waktunya dapat diperhitungkan jauh sebelumnya. Namun fakta di atas menunjukkan bahwa kebanyakan rumah tangga di Indonesia masih belum mampu melakukan perencanaan biaya pendidikan dengan baik. Hal ini dapat disebabkan oleh berbagai hal, diantaranya adalah kondisi keuangan keluarga yang kurang sehat, rendahnya kesadaran akan pentingnya melakukan perencanaan keuangan khususnya perencanaan biaya pendidikan, ketidakmampuan melakukan perencanaan biaya pendidikan, dan sebab-sebab lainnya. Oleh karenanya diperlukan diseminasi pola pengelolaan keuangan rumah tangga, khususnya dalam perencanaan biaya pendidikan.

Berdasarkan latar belakang dan masalah di atas, maka kegiatan pengabdian kepada masyarakat (PKM) ini bertujuan untuk menyebarluaskan cara melakukan pengecekan kesehatan keuangan rumah tangga dan meningkatkan kesadaran pentingnya perencanaan 
biaya pendidikan, dan memberikan pemahaman tentang cara melakukan perencanaan biaya pendidikan anak.

Sasaran kegiatan PKM adalah para pengelola keuangan rumah tangga, yang rumah tangganya memiliki anak usia pra-sekolah dan usia sekolah (1-19 tahun). Diseminasi dilakukan pada Komunitas lbu RT 09 RW 03 Kelurahan Dukuh Kecamatan Kramat Jati Jakarta Timur.

Kegiatan ini diharapkan dapat (a) meningkatkan literasi keuangan perempuan, khususnya para ibu rumah tangga yang bertugas mengelola keuangan rumah tangga; (b) meningkatkan kesehatan keuangan rumah tangga sehingga tercipta rumah tangga-rumah tangga yang tangguh dalam hal keuangan; (c) mengurangi angka putus sekolah karena masalah biaya; (d) mengurangi NPL kartu kredit.

\section{METODE PELAKSANAAN}

Tahapan dan jadwal kegiatan PKM adalah sebagaimana terlihat pada Tabel 1.

Tabel 1

Tahapan dan Jadwal Kegiatan

\begin{tabular}{|c|l|l|l|l|l|l|}
\hline \multirow{2}{*}{ No. } & \multicolumn{1}{|c|}{ Kegiatan } & \multicolumn{4}{|c|}{ Bulan, 2018-2019 } \\
\cline { 3 - 6 } & & Sep. & Okt. & Nov. & Des. & Jan. \\
\hline 1 & Penyusunan Proposal & & & & & \\
\hline 2 & $\begin{array}{l}\text { Persiapan Kerjasama } \\
\text { dengan Komunitas }\end{array}$ & & & & & \\
\hline 3 & Penyusunan Modul & & & & & \\
\hline 4 & $\begin{array}{l}\text { Persiapan \& } \\
\text { Pelaksanaan }\end{array}$ & & & & & \\
\hline 5 & $\begin{array}{l}\text { Penyusunan Laporan \& } \\
\text { Pelaporan }\end{array}$ & & & & & \\
\hline
\end{tabular}

Kegiatan PKM ini dilaksanakan dengan metode ceramah dan active learning, dengan durasi kegiatan diseminasi selama 2 jam (120 menit). Beberapa teknik dalam activelearning yang digunakan adalah:

(a) True or False: untuk mengetahui tingkat literasi keuangan peserta

(b) Card sort: untuk melakukan self-assessment terhadap kesehatan keuangan rumah tangga peserta

(c) Giuded teaching: untuk memberikan pengetahuan tentang perencanaan biaya pendidikan

(d) Tanya jawab dan diskusi: untuk membahas kasus dan melakukan wrap-up atas keseluruhan kegiatan yang telah dilakukan

Bahan dan peralatan (logistik) yang digunakan adalah sebagai berikut:

(a) Kuis untuk mengetahui tingkat literasi keuangan para peserta 
(b) Kuis untuk mengetahui kesehatan keuangan rumah tangga para peserta

(c) Modul dalam bentuk power-point untuk ceramah

(d) Souvenir

\section{HASIL DAN PEMBAHASAN}

\subsection{Persiapan}

Dalam rangka pelaksanaan kegiatan, pelaksana melakukan kegiatan persiapan yang meliputi menghubungi ketua komunitas sasaran, melakukan profiling anggota komunitas sasaran, menyusun materi kegiatan dan menyiapkan logistik kegiatan. Berikut ini penjelasan atas ke-4 kegiatan tersebut.

\section{(a) Menghubungi Ketua Komunitas Sasaran}

Berdasarkan tujuan kegiatan, maka telah ditetapkan komunitas sasaran kegiatan, yaitu Komunitas Ibu di lingkungan RT 09 RW 03 Kelurahan Dukuh Kecamatan Kramat Jati Jakarta Timur. Komunitas ini dipimpin oleh seorang sesepuh, yaitu lbu Ning Darma yang berusia 70 tahun. Melalui lbu Ning Darma, pelaksana melakukan pendekatan untuk dapat melakukan kegiatan diseminasi pada komunitas yang dipimpinnya.

Awalnya pelaksana melakukan hubungan melalui WhatsApp (WA) untuk menyampaikan maksud dan tujuan kegiatan. Setelah mendapatkan tanggapan yang memadai, pelaksana melakukan kunjungan langsung untuk membahas tempat dan jadwal kegiatan serta susunan acara. Pada akhir kunjungan disepakati bahwa kegiatan akan dilaksanakan pada Minggu, 2 Desember 2018, pada jam 16.00-18.00 WIB

\section{(b) Melakukan Profiling Anggota Komunitas Sasaran}

Selanjutnya, setelah mendapatkan persetujuan dari ketua komunitas dan jadwal kegiatan, pelaksana melakukan profiling anggota komunitas. Hasil profiling digunakan oleh pelaksana untuk menyusun kedalaman materi dan pemilihan kosa kata/terminologi agar materi diseminasi yang akan disampaikan sesuai dengan kebutuhan dan dapat dikomunikasikan dengan bahasa yang mudah dipahami. Hal ini dilakukan agar kegiatan dapat berjalan efektif, dalam arti mampu mencapai tujuannya.

Profiling dilakukan dengan melakukan pengamatan langsung di lapangan oleh pelaksana dan mendapatkan konfirmasi dari salah satu pengurus komunitas, yaitu Ibu Puji yang merupakan bendahara dari komunitas tersebut.

Hasil profiling menunjukkan bahwa lebih kurang $70 \%$ komunitas adalah ibu dengan putra/putri usia pra-sekolah dan usia sekolah, mulai dari TK, SD, SMP, dan SMA. Sedangkan sisanya adalah ibu dengan putra yang sedang kuliah, sudah menikah dan 
memiliki cucu. Dilihat dari tingkat pendidikannya, 20\% adalah lulusan SD dan SMP, 73\% adalah lulusan SMA dan 7\% lulusan perguruan tinggi (diploma dan sarjana).

\section{(c) Menyusun Materi Diseminasi}

Berdasarkan hasil profiling, disusunlah materi sosialisasi dengan mempertimbangkan tingkat pendidikan sasaran dan tingkat pendidikan anak-anaknya. Materi diseminasi disusun sedemikian rupa sehingga informasi yang akan disampaikan benar-benar materi yang diperlukan oleh anggota komunitas sasaran. Materi tersebut merupakan hasil kompilasi dari berbagai sumber, yaitu Li Ka-Shing (2014), Diyanto (2015), Kompas (2016), OJK (2016b), Wahyuni (2017), Waringin (2017), Dinas Pendidikan Kepulauan Riau (2018), Finansialku.com (2018), dan Guarav (2018). Pokok-pokok isi materi ceramah adalah (a) perlunya dilakukan pengelolaan keuangan rumah tangga yang baik; (b) perlunya melakukan perencanaan biaya pendidikan; (c) prediksi besarnya biaya pendidikan di masa yang akan datang; dan (d) teknik perencanaan biaya pendidikan.

Materi tersebut dirancang untuk dapat disampaikan selama 30 menit dalam bentuk ceramah dan dapat memancing keingintahuan dari komunitas sasaran sehingga dapat dilanjutkan dengan tanya jawab dan diskusi. Sesi tanya jawab dan diskusi dirancang selama $60-90$ menit.

Selain materi tersebut, disusun pula sejumlah pertanyaan untuk mengetahui kondisi keuangan rumah tangga, literasi keuangan pengelola keuangan rumah tangga, dan pola pengelolaan keuangan rumah tangga. Pertanyaan-pertanyaan tersebut disampaikan dalam format kuis lisan dan dijawab secara lisan pula oleh para peserta.

\section{(d) Menyiapkan Logistik Kegiatan}

Menjelang hari pelaksanaan, pelaksana menyiapkan logistik kegiatan yang meliputi fotokopi materi, daftar hadir, dan souvenir. Materi diseminasi dan souvenir yang disiapkan adalah sejumlah 40 paket. Foto souvenir adalah sebagaimana terlampir.

\subsection{Pelaksanaan Kegiatan}

Kegiatan diseminasi dilaksanakan pada Minggu, 2 Desember 2018 jam 16.05-18.00 WIB bertempat di Kediaman Ibu Mulyono (salah satu anggota komunitas sasaran) yang beralamat di RT 09 RW 03 Keluarahan Dukuh Kecamatan Kramat Jati Jakarta Timur.

Realisasi susunan acara adalah sebagaimana terlihat pada Tabel 2. Kegiatan diseminasi dihadiri oleh 24 orang dari 40 orang anggota komunitas. Sepanjang ceramah dilaksanakan, peserta menunjukkan perhatian yang tinggi. Hal ini terlihat dari tidak adanya peserta yang mengobrol atau menggunakan gadget selama ceramah berlangsung. Pada acara kuis, tanya jawab dan diskusi, peserta menunjukkan antusiasme yang tinggi. Hal ini 
terlihat dari banyaknya pertanyaan dan aktifnya peserta dalam diskusi. Suasana selama acara berlangsung dapat dilihat pada foto-foto terlampir.

Tabel 2

Realisasi Susunan Acara

\begin{tabular}{|c|l|l|}
\hline Jam & \multicolumn{1}{|c|}{ Kegiatan } & \multicolumn{1}{c|}{ PIC } \\
\hline $16.05-16.10$ & Pembukaan & Ketua Komunitas: Ibu Ning Darma \\
\hline $16.10-16.40$ & Ceramah & Farida Komalasari \\
\hline $16.40-17.40$ & Tanya Jawab \& Diskusi & $\begin{array}{l}\text { Farida Komalasari } \\
\text { Eko Ganiarto }\end{array}$ \\
\hline $17.40-17.50$ & Penutupan & Ketua Komunitas: Ibu Ning Darma \\
\hline $17.50-18.00$ & Pembagian Souvenir & Bendahara Komunitas: Ibu Puji \\
\hline
\end{tabular}

Beberapa pertanyaan yang disampaikan dan menjadi bahan diskusi adalah:

(a) Berapa persen dari penghasilan yang harus disimpan untuk cadangan uang sekolah anak, jika anaknya dua dan saat ini berusia 7 tahun dan 4 tahun?

(b) Apakah menabung untuk uang sekolah anak harus dimulai sejak anak masih dalam kandungan?

(c) Berapakah uang yang harus dicadangkan untuk sekolah anak sampai lulus sarjana, jika sekarang anaknya berumur 3 tahun?

(d) Manakah yang lebih baik, menabung di bank atau membeli perhiasan?

(e) Manakah yang lebih menguntungkan, membeli perhiasan atau membeli emas batangan?

(f) Manakah yang lebih baik, membeli emas batangan atau tanah?

(g) Apakah menabung pada tabungan pendidikan yang ditawarkan oleh bank akan menguntungkan?

(h) Manakah yang lebih baik, menabung dengan jumlah tertentu setiap bulan dengan disiplin atau mengikutsertakan anak dalam asuransi pendidikan?

(i) Manakah yg lebih baik, apakah menabung sendiri secara disiplin atau menabung melalui tabungan pendidikan?

(j) Bagaimana memilih asuransi pendidikan yang menjamin bahwa uang pendidikan benarbenar akan dibayarkan oleh perusahaan asuransi pada saat jatuh tempo?

Bahkan, ada beberapa pertanyaan di luar topik yang dibahas, diantaranya adalah pertanyaan tentang perbedaan antara bank konvensional dengan bank syariah, bagaimana memilih sekolah yang baik, bagaimana memilih asuransi yang baik, asuransi apa saja yang sebaiknya dimiliki oleh keluarga, dan bahkan pertanyaan tentang bagaimana caranya agar anak tidak ketagihan bermain gadget.

Mengingat keterbatasan waktu, meskipun antusiasme peserta masih tinggi, maka acara tanya jawab dan diskusi diakhiri pada pukul 17.40 karena sudah menjelang 
pelaksanaan sholat Maghrib. Di akhir acara, ketua komunitas menyampaikan keinginan para anggotanya untuk dilaksanakan kegiatan sejenis dengan topik yang berbeda. Beberapa topik yang diusulkan diantaranya adalah kiat menabung, memilih lembaga asuransi, memilih instrumen investasi, dan mendidik anak pada era digital.

\subsection{Evaluasi Kegiatan}

Evaluasi dilakukan atas alasan pemilihan topik (why), materi yang disampaikan (what), kelompok sasaran dan tempat penyelenggaraan (where), jadwal dan durasi penyelenggaraan (when), dan cara/metode diseminasi yang digunakan (how). Berikut ini uraian evaluasi atas kelima hal tersebut:

\section{(a) Evaluasi atas Alasan Pemilihan Topik}

Diawali dengan adanya fenomena meningkatnya aktivitas gadai dan pinjam menjelang awal tahun pelajaran sebagai jalan keluar atas masalah ketersediaan biaya pendidikan sebagaimana diuraikan pada Pendahuluan, maka pelaksana tertarik untuk mengadakan acara diseminasi pola pengelolaan keuangan rumah tangga dengan mengambil tema pokok perencanaan biaya pendidikan. Setelah dikonfirmasi kepada calon kelompok sasaran, terkonfirmasi bahwa fenomena yang sama juga terjadi pada kelompok sasaran. Oleh karenanya penetapan Komunitas Ibu RT 09 RW 03 Kelurahan Dukuh Kecamatan Kramat Jati Jakarta Timur adalah keputusan yang sangat tepat. Materi yang disampaikan merupakan materi yang diperlukan oleh peserta untuk memperbaiki pola pengelolaan keuangan rumah tangganya dengan memasukkan biaya pendidikan anak sebagai prioritas.

\section{(b) Evaluasi atas Materi}

Secara keseluruhan dapat dikatakan bahwa acara berlangsung dengan lancar dan materi yang disampaikan dapat dipahami dan dirasakan sangat bermanfaat bagi para peserta. Hal ini terlihat dari tingginya antusiasme peserta pada saat mengikuti ceramah dan pada saat acara kuis, tanya jawab dan diskusi berlangsung. Banyaknya pertanyaan yang terkait dengan materi menunjukkan bahwa peserta memahami materi yang disampaikan dan tertarik untuk mengetahui lebih banyak lagi. Materi yang telah disusun dengan mempertimbangkan profil peserta terbukti mampu menarik perhatian dan memudahkan peserta memahaminya.

Pertanyaan yang disampaikan serta kasus yang diutarakan menunjukkan bahwa peserta selama ini memerlukan pihak lain yang dapat memberikan masukan dan membantu memecahkan persoalan yang dihadapinya. Selama ini, peserta tidak dengan baik menghitung dan menyiapkan biaya sekolah untuk anak-anaknya. Kesulitan keuangan yang dialami setiap menjelang tahun ajaran baru menjadi masalah rutin bagi sebagian besar 
peserta. Acara ini mereka rasakan membuka wawasan tentang pentingnya membuat perencanaan biaya pendidikan bagi anak. Untuk membuat perencanaan biaya pendidikan yang baik, diperlukan pengetahuan tentang perkembangan biaya sekolah, jumlah dana yang harus disiapkan, alternatif pilihan menabung, dan lain-lain. Oleh karenanya para peserta sangat antusias mengikuti acara dari awal hingga akhir.

Berdasarkan ragam pertanyaan yang diajukan dan kasus yang disampaikan, terlihat bahwa para peserta menginginkan adanya acara sejenis di kesempatan lain dengan topik yang berbeda. Beberapa topik yang diusulkan adalah sebagaimana telah disebutkan sebelumnya.

\section{(c) Evaluasi atas Kelompok Sasaran dan Tempat Penyelenggaraan}

Sebagaimana diuraikan di atas, kelompok sasaran kegiatan ini adalah Komunitas Ibu RT 09 RW 03 Kelurahan Dukuh Kecamatan Kramat Jati Jakarta Timur. Berdasarkan profiling yang dilakukan pada tahap persiapan, terlihat bahwa sebagian besar dari kelompok sasaran adalah ibu rumah tangga dari sebuah keluarga yang memiliki anak pra-sekolah dan yang sedang menempuh pendidikan pada jenjang SD, SMP dan SMA. Oleh karenanya kelompok ini sangat tepat untuk mendapatkan materi diseminasi tentang perencanaan biaya pendidikan.

Acara dilangsungkan di salah satu rumah anggota komunitas (Ibu Mulyono) yang cukup memadai. Acara berlangsung di ruang tamu dan teras depan, sehingga peserta terbagi menjadi dua kelompok. Jika dimungkinkan, pada kesempatan lain dapat dipilih lokasi yang lebih luas, misalnya di Balai RW atau di tempat-tempat ibadah; sehingga peserta dapat menyatu.

\section{(d) Evaluasi atas Jadwal dan Durasi Penyelenggaraan}

Berdasarkan kesepakatan antara ketua komunitas dan pelaksana, acara diselenggarakan pada hari Minggu, 2 Desember 2018 jam 16.00-18.00. Namun pada pelaksanaannya, acara dimulai mundur 5 menit dari yang telah dijadwalkan karena menunggu kehadiran ketua komunitas.

Desember merupakan waktu yang sangat tepat karena 6 bulan menuju tahun ajaran baru, sehingga para ibu memiliki waktu yang cukup untuk mempersiapkan biaya pendidikan pada tahun ajaran baru yang akan datang, yang biasanya jatuh pada bulan Juni-Juli.

Dipilihnya jam 16.00-18.00 WIB dilakukan dengan mempertimbangkan kesibukan para ibu yang sangat padat di pagi hari dan kurang padat di sore hari; dengan demikian diharapkan jumlah anggota komunitas yang hadir akan lebih banyak. Harapan ini terjawab dengan hadirnya sejumlah 24 orang dari 40 orang anggota yang terdaftar. 
Terkait dengan durasi penyelenggaraan, dua jam adalah waktu yang tepat meskipun belum dapat menampung semua pertanyaan peserta. Namun jika acara dilangsungkan dengan durasi yang lebih panjang, maka dapat mengakibatkan melebarnya topik bahasan dan tidak fokus pada topik utama, yaitu perencanaan biaya pendidikan.

\section{(e) Evaluasi atas Metode/Cara Diseminasi yang Digunakan}

Metode ceramah, kuis, tanya jawab dan diskusi yang digunakan pada acara ini dinilai sangat tepat. Ceramah sepanjang 30 menit dirasakan tidak terlalu panjang dan membosankan. Hal ini terlihat dari tingginya perhatian peserta dan suasana yang tercipta ketika ceramah berlangsung.

Kuis, tanya jawab dan diskusi yang berlangsung selama 1 (satu) jam juga dirasakan masih kondusif untuk membuat peserta fokus pada kegiatan yang tengah berjalan. Tidak semua pertanyaan dari peserta dapat ditampung dalam durasi yang singkat tersebut, namun beberapa pertanyaan yang disampaikan dianggap telah cukup mewakili aspirasi peserta.

\section{KESIMPULAN}

Kesuksesan keluarga dalam mengelola keuangan rumah tangga khususnya dalam perencanaan biaya pendidikan akan berkontribusi dalam mengantarkan suksesnya anak dalam menempuh pendidikan. Sebagaimana diketahui, hingga saat ini pendidikan masih merupakan salah satu syarat perlu (necessary condition) untuk melakukan migrasi vertikal. Pendidikan yang baik akan berperan dalam mendapatkan pekerjaan yang baik, yang pada akhirnya akan dapat mengangkat tingkat kehidupan, kondisi ekonomi dan status sosial keluarga.

Hal tersebut tentunya telah disadari oleh banyak rumah tangga. Namun tidak banyak rumah tangga yang secara sadar telah melakukan perencanaan biaya pendidikan dengan baik. Oleh karenanya diseminasi pola pengelolaan keuangan rumah tangga, khususnya dalam perencanaan biaya pendidikan sangatlah diperlukan. Melalui kegiatan ini diharapkan lebih banyak rumah tangga yang mampu mengantarkan anak-anaknya sukses dalam pendidikan tanpa kendala biaya

Melihat tingginya antusiasme peserta dan banyaknya pertanyaan serta kasus yang disampaikan, maka kegiatan sejenis dapat diselenggarakan dengan komunitas sasaran yang berbeda. Dengan demikian ilmu pengetahuan yang dikembangkan oleh perguruan tinggi benar-benar dapat dirasakan manfaatnya oleh masyarakat. 


\section{UCAPAN TERIMA KASIH}

Atas terlaksananya kegiatan PKM ini, pelaksana menyampaikan penghargaan dan terimakasih atas dukungan pemikiran, sumbang saran, partisipasi, dan dukungan pendanaan, kepada:

(a) Rektor Universitas Presiden

(b) Direktur Lembaga Riset dan Pengabdian Masyarakat Universitas Presiden

(c) Ketua RT 009/RW 03 Kelurahan Dukuh, Kecamatan Kramat Jati, Jakarta Timur

(d) Ibu Ning Darma selaku Pimpinan Komunitas lbu di lingkungan RT 09 RW 03 Kelurahan Dukuh, Kecamatan Kramat Jati, Jakarta Timur

(e) Para ibu anggota Komunitas Ibu di lingkungan RT 09 RW 03 Kelurahan Dukuh, Kecamatan Kramat Jati, Jakarta Timur

(f) Saudari Btari A. Ratnakanya

\section{REFERENSI}

Dinas Pendidikan Kepulauan Riau. (2018). 7 Tips Merancang Dana Pendidikan Anak. Diunduh dari https://www.disdik.kepriprov.go.id

Diyanto, A. (2015). Ciri Keuangan yang Sehat dalam Rumah Tangga. Diunduh dari vw10/blogspot.com

Finansialku.com. (2018). Ibu Rumah Tangga Butuh Konsultasi Perencanaan Keuangan. Diunduh dari https://www.finansialku.com/ibu-rumah-tangga-butuh-konsultasiperencanaan-keuangan/

Franedya, R. \& Indradie, A. (2009). NPL Kartu Kredit Masih Tinggi. Diunduh dari kontan.co.id

Guarav, M. (2018). Financial Planning. Diunduh dari https://www.google.com/search?q=distribusi+keuangan+rumah+tangga\&client=firefo $x$-b-ab\&source=Inms\&tbm=isch\&sa $=X \& v e d=0 a h U K E w j W m O H g h-$ 7bAhVHXisKHQQVA70Q AUICigB\&biw=1600\&bih=786\#imgrc=td5mzJRKuZ xM:

Kompas. (2016). Saatnya Merencanakan Biaya Pendidikan Anak Sejak Dini. Diunduh dari https://ekonomi.kompas.com

Kompas.com. (2018). Begini kondisi Literasi Keuangan Perempuan Indonesia Dibanding Negara Tetangga. Diunduh dari https://ekonomi.kompas.com

Li Ka-Shing. (2014). Li Ka-Shing Teaches You How to Buy a Car \& House in 5 Years. Diunduh dari https://e27.co/li-ka-shing-teaches-buy-car-house-5-years-20150408/

OJK. (2016a). Literasi Keuangan Indonesia Kalah dari Malaysia. Diunduh dari liputan6.com 
OJK. (2016b). Siaran Pers 9 Juni 2016: Safari Ramadhan OJK Berikan Literasi Keuangan bagi Masyarakat Pesantren untuk Meningkatkan Utilisasi Tabungan "Simpel". Diunduh dari ojk.go.id.

OJK. (2017a). OJK: Literasi Keuangan Masayarakat masih Rendah. Diunduh dari kontan.co.id

OJK. (2017b). Literasi dan Inlusi Keuangan Digenjot. Diunduh dari kontan.co.id

PSKK-UGM. (2016). Tingginya Angka Putus Sekolah di Indonesia. Diunduh dari student.cnnindonesia.com

Pulungan, D.R. (2016). Literasi Keuangan dan Dampaknya terhadap Perilaku Keuangan Masyarakat Kota Medan. Diunduh dari jurnal.umsu.ac.id

Sembiring, L.J. (2018). NPL Terbesar BRI Disumbang dari Kartu Kredit. Diunduh dari economy.okezone.com

Wahyuni, N.D. (2017). 5 Investasi yang Pas untuk Biaya Pendidikan Anak. Diunduh dari https://www.liputan6.com/bisnis/read/2947273/5-investasi-yang-pas-untuk-biayapendidikan-anak

Waringin, T.D. (2017). Apakah Keuangan Anda Sehat? Kenali 5 Ciri Berikut. Diunduh dari https://finance.detik.com 
Academics in Action Journal

Volume 1, Number 1, 2019, 8-19

\section{LAMPIRAN}

Foto-Foto Kegiatan
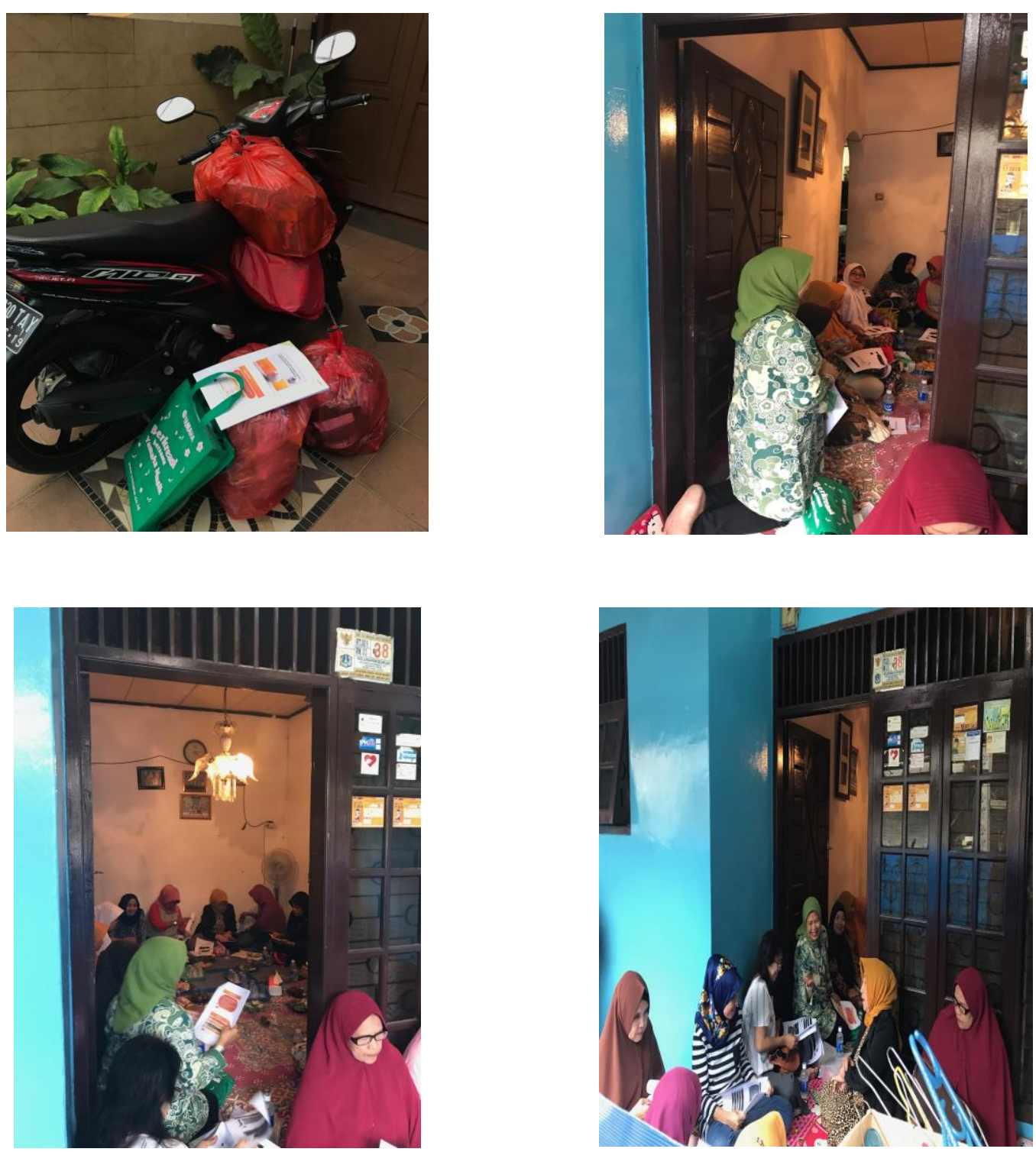